\title{
Identification of rol Genes on pRi1724 in Agrobacterium rhizogenes Strain MAFF 03-01724 Isolated in Japan
}

\author{
Nobukazu TANAKA* and Atsuhiro OKA**
}

\begin{abstract}
Agrobacterium rhizogenes strain MAFF 03-01724 isolated from a diseased melon plant bears pRi1724, a mikimopine-type of hairy-root-inducing plasmid. The 9.5-kb region of pRi1724 showed the root-inducing ability toward leaf disks of Ajuga reptans and Nicotiana tabacum. This region contained sequences highly homologous to each of the rolA, rolB, and rolC genes of the agropine-type hairy-root-inducing plasmid pRiA4b. The relative position of the three homologs was the same as that of pRiA4b. These results indicate that pRi1724 carries genes both functionally and structurally equivalent to the $r o l A, r o l B$ and $r o l C$ genes of pRiA4b.
\end{abstract}

(Received May 19, 1993)

Key words : Agrobacterium rhizogenes, hairy-root-inducing plasmid (pRi), transferred DNA (T-DNA), rooting locus (rol) gene, hybridization.

\section{INTRODUCTION}

The soil phytopathogenic bacterium Agrobacterium rhizogenes causes the hairy root syndrome in many dicotyledonous plants ${ }^{3}$. The neoplastic roots induced upon infection contain a portion of bacterial plasmid DNA. The causative plasmid is termed hairy-root-inducing plasmid (pRi). The T-DNA includes genes essential for root induction and for synthesis of unique amino acid derivatives called opine ${ }^{14)}$. In the case of agropine-type pRiA4b, it is known that four genes $(\operatorname{rol} A, \operatorname{rol} B$, rolC, and $\operatorname{rol} D)$ are required for root induction ${ }^{20}$. The $r o l B$ gene codes for a $\beta$-glucosidase capable of hydrolyzing indole- $\beta$ glucosides, leading to the increase of active auxin level by release of auxins from its inactive $\beta$ glucosides in transgenic plants ${ }^{5}$. The rolC gene encodes another $\beta$-glucosidase that hydrolyzes cytokinin- $\beta$-glucosides ${ }^{4}$. Other rol gene products have not yet been characterized biochemically. Moreover, molecular mechanisms of initiation of root induction by these rol gene products have not been elucidated.

A. rhizogenes strains, MAFF 03-01724 to 03-01727 (carrying pRi1724 to 1727, respectively), have been isolated from diseased melon plants in Japan ${ }^{17}$, and characterized as a producer of a new opine called mikimopine ${ }^{8)}$, a stereoisomer of cucumopine ${ }^{2)}$. We previously constructed pRi1724 gene libraries with the plasmid and cosmid vectors, and characterized its T-DNA region ${ }^{19)}$. During course of the study, it was found that pRi1724 contains DNA regions highly homologous to the core T-DNA region of pRiA4b. Since the pRiA4b core T-DNA contains the four rol genes ${ }^{20)}$, pRi1724 appears to have functionally similar genes.

In this article, we show the precise mapping of the rol gene homologs on pRi1724 by Southern-blot hybridization experiments, and demonstrate that DNA fragments carrying these homologs can be independently identified by means of initiation of hairy roots on leaf disks by infection with $A$. tumefaciens harboring binary vectors bearing test DNA fragments.

* Research Center, Daicel Chemical Industries, Ltd., Shinzaike 1239, Aboshi-ku, Himeji, Hyogo 671-12, Japan ダイセル化学工業 (侏) 総合研究所

** Laboratory of Molecular Genetics, Institute for Chemical Research, Kyoto University, Uji, Kyoto 611, Japan 京都大学化学研究所 


\section{MATERIALS AND METHODS}

General methods. As described were culture media, chemicals, enzymes, and procedures for transformation of Escherichia coli, bacterial conjugation, preparation of plasmid DNA, DNA cleavage with restriction enzymes, purification of DNA fragments, and ligation of DNA fragments ${ }^{7,10,16,19)}$. Electrophoresis of DNA was carried out on $0.7 \%$ agarose gel for $4 \mathrm{hr}$ at $80 \mathrm{~V}$ in TAE buffer $(40 \mathrm{mM}$ Tris-acetate, 2 mM EDTA, pH 7.6).

Bacteria and plasmids. Agrobacterium rhizogenes strain MAFF 03-01724 isolated from a diseased melon plant in Japan ${ }^{17)}$ was used in the present study. A. tumefaciens strain LBA4404 (Toyobo Co., Ltd.) was used for infection on plants. The E. coli strain JM109 ${ }^{21)}$ was used for construction of recombinant plasmids. The $E$. coli strain RK2013 (Toyobo) was used as a helper bacterium for plasmid transfer from E. coli strain JM109 to A. tumefaciens strain LBA4404. Plasmids described below were introduced to these bacterial strains by transformation as needed. Plasmids used were a binary vector pBIN19 (Toyobo) and E. coli cloning vectors pUC18 (ampicillin-resistant) and pHSG298 (kanamycinresistant) (Takara). The recombinant plasmid pRIB106, a clone in plasmid library, carried a portion of the pRi1724 T-DNA on the BamHI site of pBR329 as described in our previous paper ${ }^{19)}$.

Plasmids carrying a portion of the pRi1724 T-DNA region are shown in Fig. 1 . Their vectors were pBIN19 for the three pRTBI plasmids (pRTBI5, 9, and 19), and pHSG298 for pRTB plasmids (pRTB5, 9, and 19) and pRTE7.6. The plasmid pRIB106 carries a portion of the pRi1724 T-DNA consisting of the three Bam HI fragments with sizes of $13.5 \mathrm{~kb}, 9.5 \mathrm{~kb}$, and $5.5 \mathrm{~kb}^{19)}$ (Fig. 1). Its subclones, pRTB5, pRTB9, and pRTB19 contained 13.5-kb, 9.5-kb, and 5.5-kb BamHI fragments, respectively, on pHSG298 (Fig. 1). These plasmids such as pRTBI5, pRTBI9, and pRTBI19 were the same as these subclones except that their vectors were pBIN19. Another pRIB106 subclone was pRTE7.6, which was made by joining pHSG298 with a 7.6-kb EcoRI fragment (see Fig. 1).

Both of pB330D and pB216D were deletion derivatives of cosmid clones, pBANK330 and pBANK216, carrying a portion of the pRiA4b $\mathrm{T}_{\mathrm{L}}-\mathrm{DNA}^{13)}$. Recombinant plasmids of pROLA, pROLB, and pROLC were constructed by cloning their subfragments on $\mathrm{pUC18}$, and used for rolA, rolB , and rolC probes, respectively. The DNA regions carried by these clones are indicated in Fig. 2.

Southern-blot hybridization. An ECL gene detection kit (Amersham) was used for DNA labeling, Southern blot, and detection of target sequences according to the supplier's directions. A nylon membrane (Hybond- $\mathrm{N}^{+}$, Amersham) was used for blotting. Chemiluminescence signal bands were

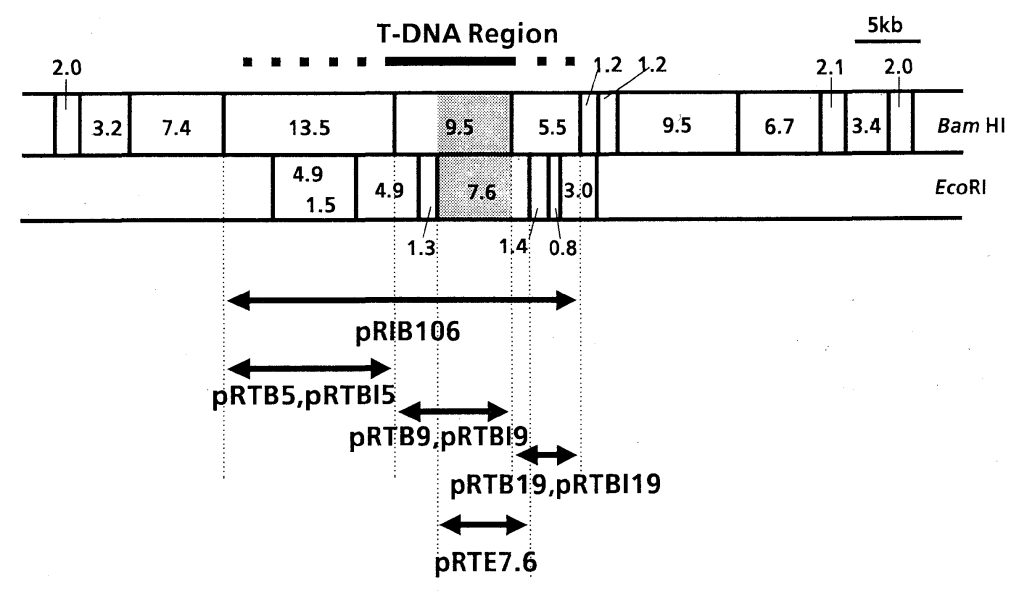

Fig. 1. Restriction map of the vicinity of pRi1724 T-DNA and its cloned fragments. The bar, marked to the upper right, represents $5 \mathrm{~kb}$. The numerals in the restriction map are the DNA sizes $(\mathrm{kb})$ of restriction fragments. The shaded rectangle indicates the 6.4-kb EcoRI-Bam HI region where three rol homologs are located. 


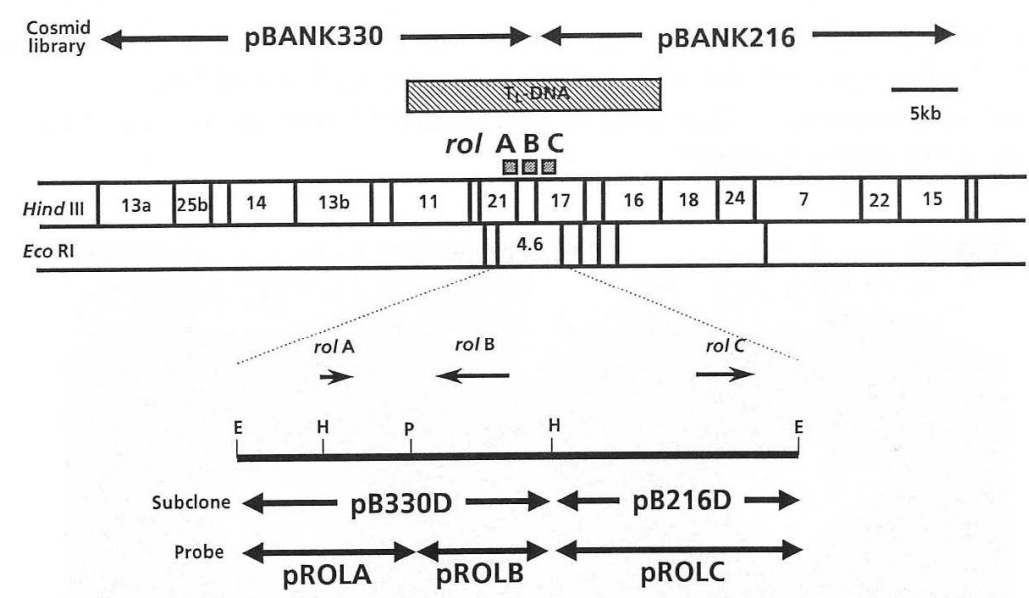

Fig. 2. Restriction map of the vicinity of $p R i A 4 b T_{L}-D N A$ and its cloned fragments. Shaded rectangles represent the position of $T_{L}$-DNA of pRi1724 and its rol genes. The bar, marked to the upper right, represents $5 \mathrm{~kb}$. The numerals in the restriction map are the DNA sizes (kb) of restriction fragments. Abbreviations: E, EcoRI; H, HindIII; P, PstI.
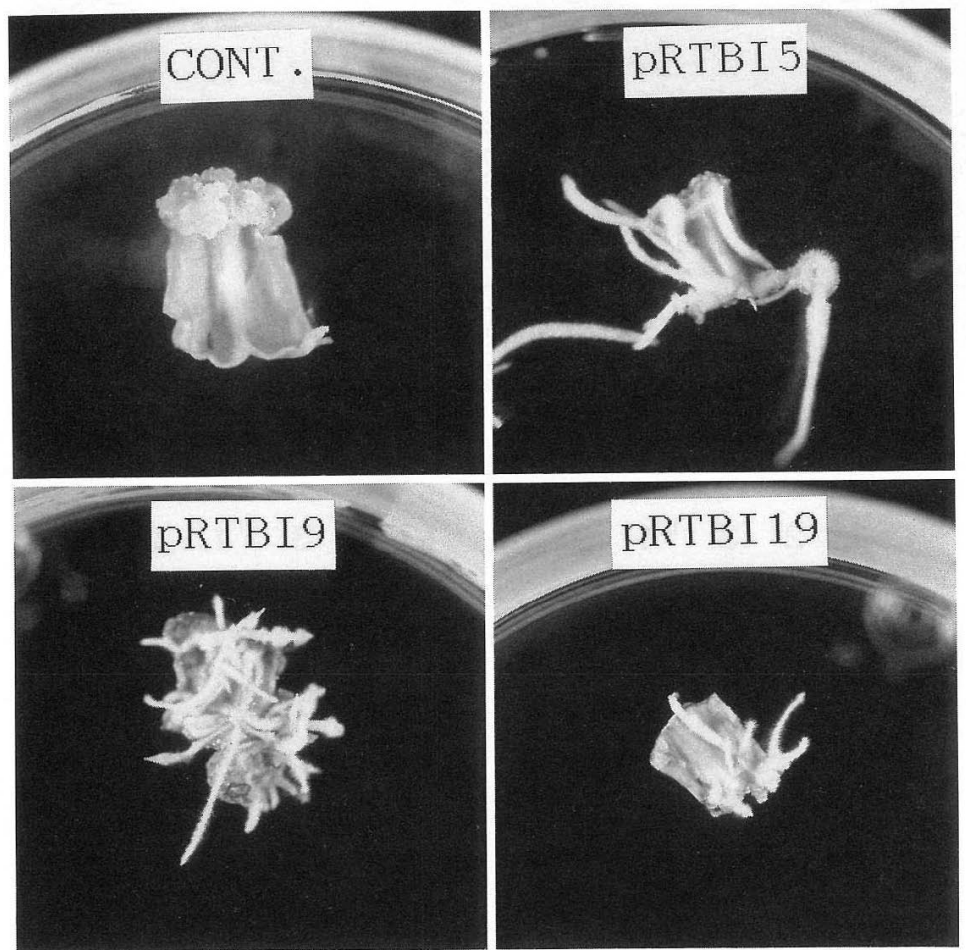

Fig. 3. Hairy roots induced on Ajuga reptans by strain LBA4404 carrying pRTBI5, pRTBI9 or pRTBI19. CONT indicates the uninoculated leaf disk. These leaf disks were cultured on MS medium at $25^{\circ} \mathrm{C}$ for 30 days after inoculation in the dark.

visualized by exposure for $30 \mathrm{sec}$ to an X-ray film (Hyperfilm, Amersham).

Agrobacterium inoculation and cultivation of roots. Leaf disks of Ajuga reptans var. atropurpurea and Nicotiana tabacum were inoculated with A. tumefaciens strain LBA4404 derivatives harboring various plasmids by briefly immersing in culture medium as described previously ${ }^{11)}$. At 4 
weeks after inoculation, induced roots were cut off from the disks and cultured on Murashige-Skoog's (MS) medium ${ }^{12)}$ solidified with $0.2 \%$ Gellungum (Wako) in the dark condition.

Detection of mikimopine. Mikimopine synthesized in root tissues was assayed with paper electrophoresis as previously described ${ }^{18)}$.

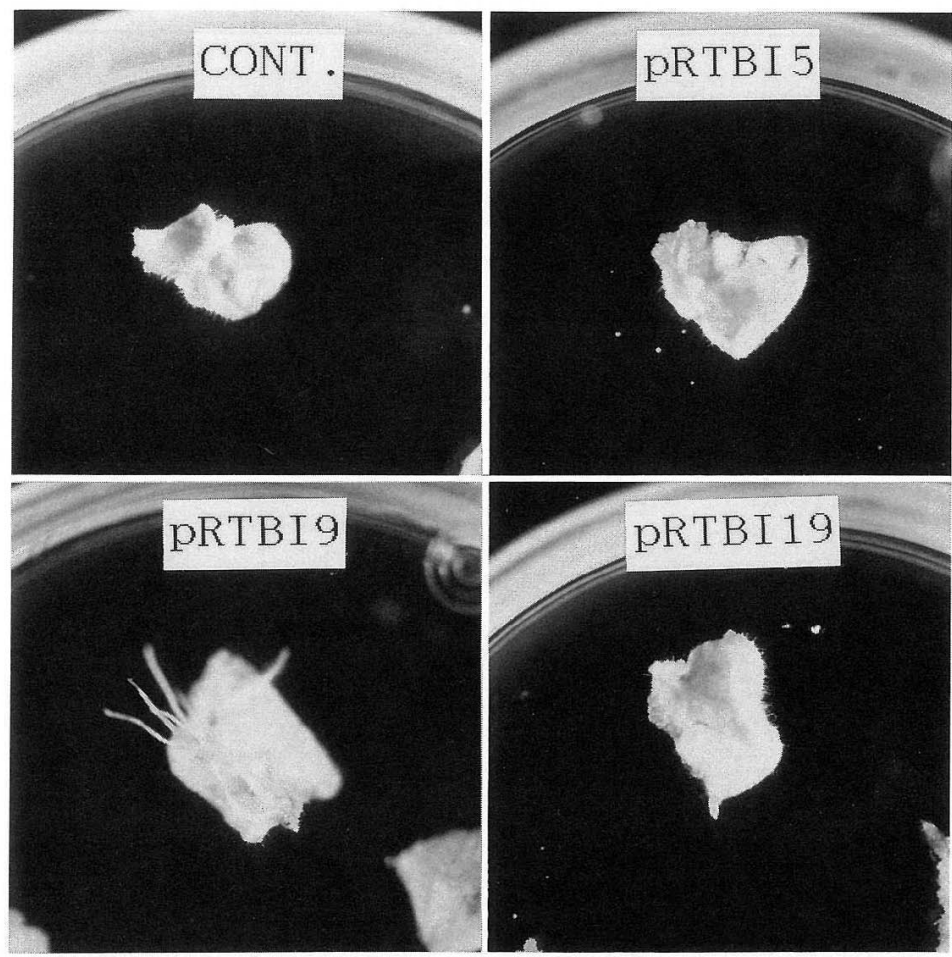

Fig. 4. Hairy roots induced on Nicotiana tabacum by strain LBA4404 carrying pRTBI5, pRTBI9 or nRTBI19. CONT indicates the uninoculated leaf disk. These leaf disks were cultured as in Fig. 3.

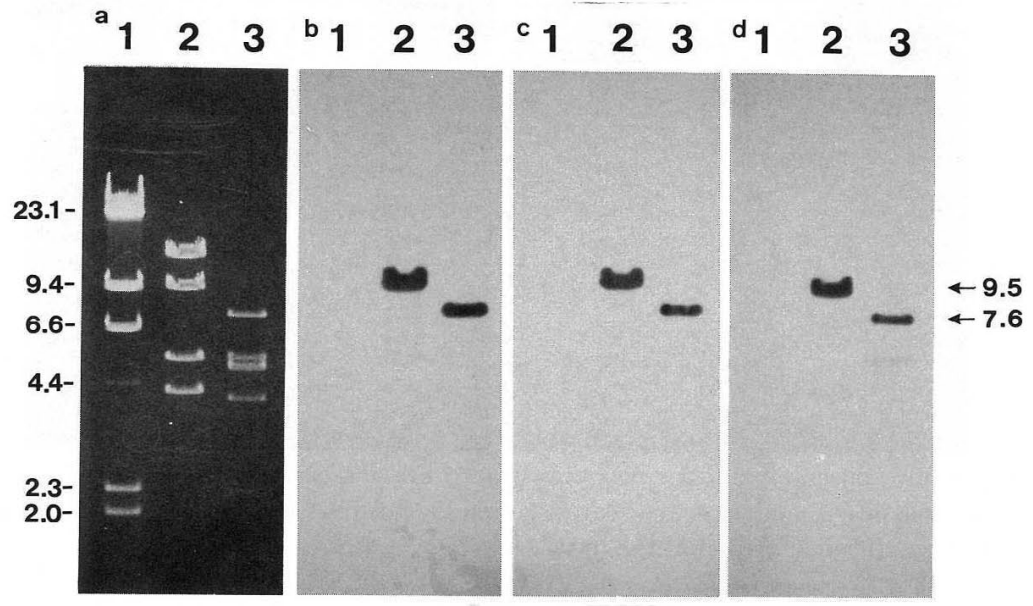

Fig. 5. Detection of $r o l$ genes on pRil724 T-DNA by Southern hybridization. The Bam HI (lane 2) and EcoRI (lane 3) digests of the pRIB106-carriers were hybridized to rolA (b), rolB (c) or rolC (d) probe of pRiA4b, respectively. Bam HI and EcoRI fragments of pRIB106 were visualized by EtBr staining (a). Numerals on the left are DNA sizes in kb referred from $\lambda /$ HindIII digests (lane 1). The figures on right represent Bam HI (9.5) and EcoRI (7.6) fragments hybridized with the probes. 


\section{RESULTS AND DISCUSSION}

\section{Ability of root induction by DNA fragments from pRi1724}

A 30-kb region of pRi1724 carried by pRIB106 was extremely close to the core $T_{L}-D N A$ region of pRiA4b ${ }^{19)}$. For further dissection of this region, the three Bam HI fragments, $13.5 \mathrm{~kb}, 9.5 \mathrm{~kb}$, and $5.5 \mathrm{~kb}$ (Fig. 1) on pRIB106 were separately inserted into pBIN19, and the resulting recombinant plasmids were named pRTBI5, pRTBI9, and pRTBI19, respectively. Each of these three plasmids were introduced into A. tumefaciens strain LBA4404 by the triparental mating method ${ }^{10)}$. A. reptans and $N$. tabacum were inoculated with the plasmid-carriers. In the case of $A$. replans, all of the three plasmid-carriers developed adventitious roots though the pRTBI9-carrier gave more intensive results than the pRTBI5and pRTBI19-carriers (Fig. 3). These induced roots could be cultured on MS medium for so fairly long period as roots made by infection with the parental $A$. rhizogenes strain 1724 (data not shown). However, growth of the former roots were generally less vigorously than that of the latter roots (data not shown). In the case of $N$. tabacum, adventitious root formation occurred only with the pRTBI9-carrier infection (Fig. 4). In addition, the initiated roots were feeble, and could not be maintained on MS medium. The difference of hairy-root-initiation between these plants may depend upon their original rooting-

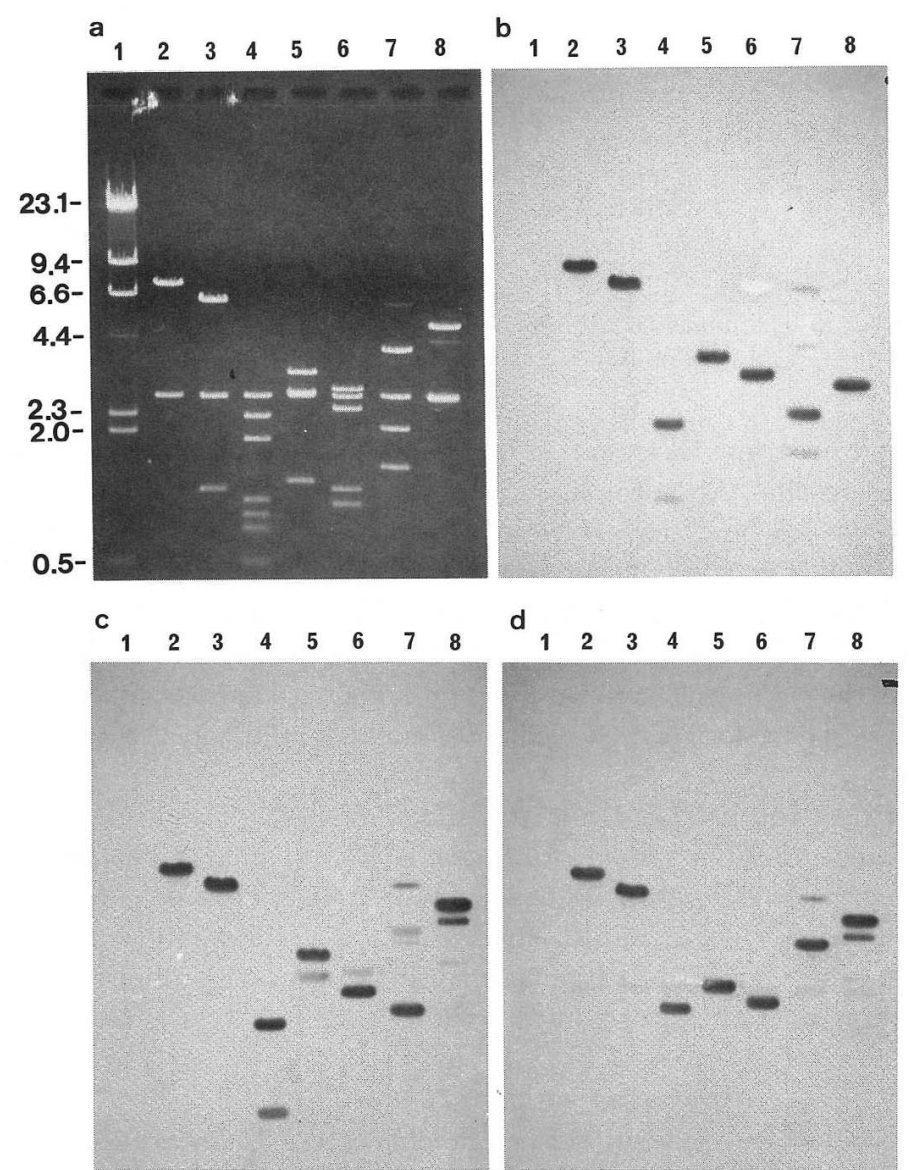

Fig. 6. Detection of rol genes on the 7.6-kb EcoRI fragment of pRi1724. pRTE7.6 was digested by Eco RI (lane 2) together with Bam HI (lane 3), ApaI (lane 4), BglII (lane 5), KpnI (lane 6), NaeI (lane 7) or SplI (lane 8). a: EtBr staining; b-d: hybridization with the rolA probe (b), rolB probe (c), and rolC probe (d). Fragment sizes are shown in the left as in Fig. 5. 
Table 1. Restriction fragments of pRTE7.6 by digestion with several enzymes and Southern hybridization for detection of rol genes in pRi1724

\begin{tabular}{|c|c|c|}
\hline Probe & Enzyme & Fragments $(\mathrm{kb})^{\mathrm{a})}$ \\
\hline \multicolumn{3}{|l|}{ rolA } \\
\hline & Eco RI & 7.6 \\
\hline & Eco RI-BamHI & $\underline{6.4}, 1.2$ \\
\hline & $E c o \mathrm{RI}-A p a \mathrm{I}$ & $\overline{2.2}, 1.9,1.1,1.0,0.8,0.6$ \\
\hline & $E c o \mathrm{RI}-B g l \mathrm{II}$ & $3.2, \overline{2.8}, 1.4, \overline{0.2}$ \\
\hline & $E c o \mathrm{RI}-K p n \mathrm{I}$ & $\underline{2.8}, 2.5,1.2,1.1$ \\
\hline & EcoRI-NaeI & $\overline{4.1}, \underline{2.0}, \underline{1.5}$ \\
\hline & $E c o \mathrm{RI}-S p l \mathrm{I}$ & $5.0, \overline{2.6}$ \\
\hline \multicolumn{3}{|l|}{ rolB } \\
\hline & Eco RI & $\underline{7.6}$ \\
\hline & EcoRI-Bam HI & $\underline{6.4}, 1.2$ \\
\hline & $E c o \mathrm{RI}-A p a \mathrm{I}$ & $\overline{2.2}, 1.9,1.1,1.0,0.8,0.6$ \\
\hline & $E c o \mathrm{RI}-B g l \mathrm{II}$ & $\underline{3.2}, \underline{2.8}, 1.4,0.2$ \\
\hline & $E c o$ RI-KpnI & $\overline{2.8}, \overline{2.5}, 1.2,1.1$ \\
\hline & EcoRI-NaeI & $\overline{4.1}, \overline{2.0}, 1.5$ \\
\hline & $E c o \mathrm{RI}-S p l \mathrm{I}$ & $\overline{5.0}, \overline{2.6}$ \\
\hline \multicolumn{3}{|l|}{ rolc } \\
\hline & Eco RI & $\underline{7.6}$ \\
\hline & EcoRI-Bam HI & $\overline{6.4}, 1.2$ \\
\hline & EcoRI-ApaI & $\underline{\underline{2.2}}, 1.9,1.1,1.0,0.8,0.6$ \\
\hline & $E c o$ RI-BglII & $\overline{3.2}, 2.8,1.4,0.2$ \\
\hline & $E c o \mathrm{RI}-K p n \mathrm{I}$ & $2.8, \overline{2.5}, 1.2,1.1$ \\
\hline & EcoRI-NaeI & $4.1,2.0,1.5$ \\
\hline & $E c o \mathrm{RI}-S p l \mathrm{I}$ & $\underline{5.0}, 2.6$ \\
\hline
\end{tabular}

a) The numerals with underline represent the fragments hybridized with probes.

responses to infection of strain 1724; that is, the response in $A$. reptans was higher than that in $N$. tabacum (unpublished results). Also, it is likely that strain LBA4404 was difficult to infect $N$. tabacum used in this experiment. Anyhow, the results as described above are consistent with the view that the principal gene responsible for root induction on plants is located in the 9.5-kb Bam HI fragment although the accessory functions enhancing the root-inducing ability are directed from both of the $13.5-\mathrm{kb}$ and $5.5-\mathrm{kb}$ Bam HI fragments. Besides, it is likely that DNA regions outside of this $30-\mathrm{kb}$ region contains genes which magnify the pathogenic activity. Since mikimopine was not synthesized in the roots induced by the pRTBI-carriers, a gene (or genes) directing synthesis of mikimopine appears to be present outside of the $30 \mathrm{~kb}$ region.

Similarity between the pRi1724 and pRiA4b T-DNAs

To identify whether the $30 \mathrm{~kb}$ region of pRi1724 T-DNA contains homologs of the $\operatorname{rolA}$, $\operatorname{rolB}$, and rolC genes of pRiA4b, Southern-blot hybridization experiments were done using the DNA fragments carrying each of the three rol genes of pRiA4b as probes. The results (Fig. 5) indicated that the 9.5-kb $B a m \mathrm{HI}$ fragment and the $7.6 \mathrm{~kb} E c o$ RI fragment are hybridized with all of the three probes. We thus concluded that the three $r o l$ homologs are located within the 6.4-kb Eco RI-Bam HI region of pRi1724 (see Fig. 1).

\section{Assignment of three rol homologs of pRi1724}

In order to precisely localize the pRi1724 rol homologs, the 7.6-kb Eco RI fragment was cleaved by digestion with either each of $A p a \mathrm{I}, B a m \mathrm{HI}, B g l \mathrm{II}, K p n \mathrm{I}, N a e \mathrm{I}$, and SplI (Fig. 6a) or their various combinations (Table 1), and a fine restriction map of the 7.6-kb EcoRI fragment was constructed (Fig. 7). After separation by gel electrophoresis, the subfragments were blotted and then hybridized to the three $r o l$ gene probes as in the preceding section (Fig. $6 \mathrm{~b}-\mathrm{d}$ ). The rolA probe hybridized with 1.9-kb 


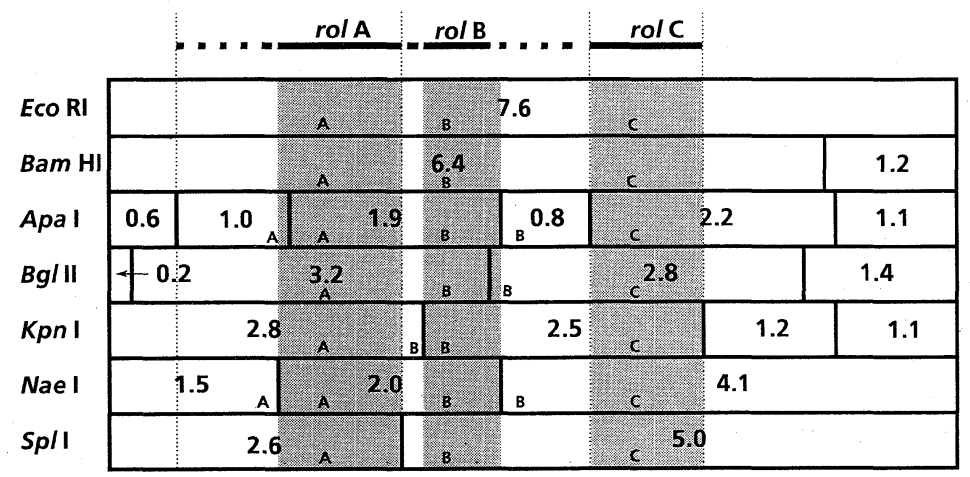

Fig. 7. A fine restriction map of the 7.6-kb EcoRI fragment of pRi1724 and the assignment of rol genes. The numerals in the map represent the fragment sizes $(\mathrm{kb})$. Capital letters in the fragments of map represent DNA hybridized to rolA $(\mathrm{A})$, rolB $(\mathrm{B})$ and rolC $(\mathrm{C})$, respectively. Shaded rectangles indicate the position of rol homologs of pRi1724.

(ApaI), 3.2-kb (BglII), 2.8-kb (EcoRI-KpnI), 2.0-kb (NaeI) and 2.6-kb (EcoRI-SplI) fragments showed strong homology, while 1.0-kb $(A p a \mathrm{I})$ and 1.5-kb (Eco RI-NaeI) ones showed weak homology (Fig. $6 \mathrm{~b})$,

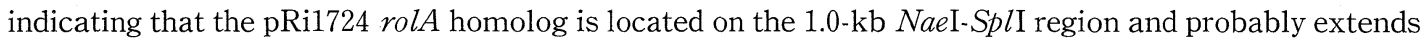
to its left side. The rolB probe was close to $1.9-\mathrm{kb}(A p a \mathrm{I}), 3.2-\mathrm{kb}(B g l \mathrm{II}), 2.5-\mathrm{kb}(K p n \mathrm{I}), 2.0-\mathrm{kb}(\mathrm{Nae} \mathrm{I})$ and $5.0-\mathrm{kb}(S p l \mathrm{I}-E c o \mathrm{RI})$ fragments showed strong homology, while 0.8-kb $(A p a \mathrm{I}), 2.8-\mathrm{kb}(B g l \mathrm{II}), 2.8-\mathrm{kb}(K p n \mathrm{I})$ and 4.1-kb (NaeI-EcoRI) ones showed weak homology (Fig. 6c), while the rolC probe was similar to $2.2-\mathrm{kb}(A p a \mathrm{I}), 2.8-\mathrm{kb}(B g l \mathrm{II}), 2.5-\mathrm{kb}(K p n \mathrm{I}), 4.1-\mathrm{kb}(N a e \mathrm{I}-E c o \mathrm{RI})$ and 5.0-kb (SplI-EcoRI) fragments showed strong homology (Fig. 6d). Therefore, the majority of the pRi1724 rolB and rolC homologs should be located on the 0.7-kb KpnI-ApaI fragment and the 1.0-kb $A p a \mathrm{I}-K p n \mathrm{I}$ fragment, respectively. The organization of these $\mathrm{rol}$ homologs was the same as that of the three rol genes of $\mathrm{pRiA} 4 \mathrm{~b}^{20)}$. These facts together with the root-inducing ability of the $9.5-\mathrm{kb} B a m \mathrm{HI}$ fragment support the view that pRi1724 bears three genes both functionally and structurally equivalent to the $r o l A$, rolB and rolC genes of pRiA4b.

The presence of rolA, rolB and rolC genes on both pRi1724 found in Japan and pRiA4b found in USA is very interesting. Filetici $e t a l .^{6}{ }^{6}$ reported that the highly conserved sequences are present on the T-DNAs of various opine-type Ri plasmids (e.g. agropine-type pRi1855 ${ }^{15)}$, mannopine-type pRi8196 ${ }^{9}$, and cucumopine-type pRi2659 ${ }^{1)}$ ). Though the spread of $A$. rhizogenes is not well understood at present for lack of enough reports on wild isolates, similar bacteria may have distributed widely all over the world. DNA sequences analysis of the pRi1724 T-DNA, which is now in progress, might further shed a light on this regard.

\section{Literature cited}

1. Combard, A., Brevet, J., Borowski, D., Cam, K. and Tempé, J. (1987). Physical map of the T-DNA region of Agrobacterium rhizogenes strain NCPPB2659. Plasmid 18: 70-75.

2. Davioud, E., Petit, A., Tate, M.E., Ryder, M.H. and Tempé, J. (1988). Cucumopine-a new T-DNA-encoded opine in hairy root and crown gall. Phytochemistry $27: 2429-2433$.

3. Elliot, C. (1951). Manual of Bacterial Plant Pathogens, 2nd Rev. ed. Chronica Botanica, Waltham, Mass.

4. Estruch, J.J., Chriqui, D., Grossmann, K., Schell, J. and Spena, A. (1991). The plant oncogene rolC is responsible for the release of cytokinins from glucoside conjugates. EMBO J. 10:2889-2895.

5. Estruch, J.J., Schell, J. and Spena, A. (1991). The protein encoded by the rolB plant oncogene hydrolyses indole glucoside. EMBO J. 10 : 3125-3128.

6. Filetici, P., Spano, L. and Costantino, P. (1987). Conserved regions in the T-DNA of different Agrobacterium rhizogenes root-inducing plasmids. Plant Mol. Biol. 9: 19-26.

7. Hanahan, D. (1985). DNA Cloning: A Practical Approach. vol. I. (Glover, D.M. ed.). IRL Press, Oxford, Washington, D.C. pp. 109-135. 
8. Isogai, A., Fukuchi, N., Hayashi, M., Kamada, H., Harada, H. and Suzuki, A. (1990). Mikimopine, an opine in hairy roots of tobacco induced by Agrobacterium rhizogenes. Phytochemistry 29:3131-3134.

9. Koplow, J., Byrne, M.C., Tempé, J. and Chilton, M.-D. (1984). Physical map of the Agrobacterium rhizogenes strain 8196 virulence plasmid. Plasmid $11: 17-27$.

10. Lichtenstein, C. and Draper, J. (1985). DNA Cloning: A Practical Approach. vol. II (Glover, D.M. ed.). IRL Press, Oxford, Washington, D.C. pp. 67-119.

11. Matsumoto, T. and Tanaka, N. (1991). Production of phytoecdysteroids by hairy root cultures of Ajuga reptans var. atropurpurea. Agric. Biol. Chem. 55 : 1019-1025.

12. Murashige, T. and Skoog, F. (1962). A revised medium for rapid growth and bioassays with tobacco tissue cultures. Physiol. Plant. 15 : 473-497.

13. Nishiguchi, R. and Oka, A. (1986). Structure of the hairy-root-inducing plasmid and identification of its replicator region. Bull. Inst. Chem. Res., Kyoto Univ. 64 : 79-87.

14. Petit, A., David, C., Dahl, G.A., Ellis, J.G., Guyon, P., Casse-Delbart, F. and Tempé, J. (1983). Further extension of the opine concept: Plasmids in Agrobacterium rhizogenes cooperate for opine degradation. Mol. Gen. Genet. 190 : 204-214.

15. Pomponi, M., Spano, L., Sabbadini, M.G. and Costantino, P. (1983). Restriction endonuclease mapping of the root inducing plasmid of Agrobacterium rhizogenes 1855. Plasmid 10: 119-129.

16. Sambrook, J., Fritsch, E.F. and Maniatis, T. (1987). Molecular Cloning: A Laboratory Manual. Cold Spring Harbor Laboratory Press, New York.

17. Shiomi, T., Shirakata, T., Takeuchi, A., Oizumi, T. and Uematsu, S. (1987). Hairy root of melon caused by Agrobacterium rhizogenes biovar 1. Ann. Phytopath. Soc. Japan 53: 454-459.

18. Tanaka, N. (1990). Detection of opines by paper electrophoresis. Plant Tissue Culture Lett. $7: 45-47$.

19. Tanaka, N., Matsumoto, T. and Oka, A. (1993). Molecular analysis of T-DNA region on the root-inducing plasmid (Ri) in a mikimopine type Agrobacterium rhizogenes. Ann. Phytopath. Soc. Japan 59: $155-162$.

20. White, F.F., Taylor, B.H., Huffman, G.A., Gordon, M.P. and Nester, E.W. (1985). Molecular and genetic analysis of the transferred DNA regions of the root-inducing plasmid of Agrobacterium rhizogenes. J. Bacteriol. $164: 33-44$.

21. Yanish-Perron, C., Vieira, J. and Messing, J. (1985). Improved M13 phage cloning vectors and host strains : nucleotide sequences of the M13mp18 and pUC19 vectors. Gene $33: 103-119$.

\section{和 文 摘 要}

田中伸和・岡 穆宏：日本産 Agrobacterium rhizogenes MAFF 03-01724 株(メロン毛根病菌)の pRi1724 上の rol 遺伝子の同定

日本産 Agrobacterium rhizogenes MAFF 03-01724 株(メロン毛根病菌)のミキモピン型毛状根誘発プラスミド pRi1724のT-DNA 上に,アジュガおよびタバコのリーフ・ディスクに毛状根を誘発する $9.5 \mathrm{~kb}$ の Bam HI 断片を見い だした。この断片上にはアグロピン型毛状根誘発プラスミド pRiA4b 上の毛状根誘発に関与する rolA, rolB および rolC 遺伝子と相同性の高い DNA 配列が存在し, その相対的位置も同様であった。以上のことから, pRi1724上には, pRiA4b の rolA, rolB および rolC 遺伝子と構造的にも機能的にも同様な遺伝子が存在することが示された。 